\title{
EDITORIAL
}

\section{The influence of emotions, attitudes and perceptions on learning with technology}

Welcome to this very international issue of Research in Learning Technology in which we present research that has been undertaken in UK, Chile, Finland, Germany, Portugal and USA. The articles on the use of technology span a range of effective teaching practices, showcase strategies for successful learning and propose ideas for future mechanisms to better engage students in their educational experiences. For me, one question running through this issue is: how is technology helping us to deliver more student-centred education?

The first article by Pedro et al. (2014) investigates the use of a recommender system across all educational sectors in Portugal. A recommender system recognises us when we return to sites previously visited such as booksellers and music download sites. They are responsive to our personal interests and offer recommendations that are aligned to our previous online transactions. Use of recommender systems in educational contexts is less common. This article explores an early implementation of a recommender system in four institutions from elementary to university level. Preliminary results highlight that the younger the learner, the more responsive they are to recommendations.

Next, a study by Kear, Chetwynd and Jefferis (2014) on social presence explores how effective personal profile pages can be in reducing student isolation. Two studies conducted at the Open University UK approximately 5 years apart illustrate that students' use of personal profile pages can be of value in developing a sense of personal connection. The extent to which students considered personal profile pages as helpful is measured across the passage of time and the change in technologies.

Another strategy for engaging students that we are increasingly seeing is the use of social media tools within the online teaching and learning dynamic. Blaschke (2014) investigates whether integration of a suite of social media tools into the learning design can aid students in developing their metacognitive skills and become more work-ready. She reports a case study of 14 cohorts of postgraduate students undertaking foundations studies of distance education and e-learning in Germany.

A study from the USA by Butz, Stupnisky and Pekrun (2015) compares online and on-campus students' emotions. This excellent piece of research greatly raises our awareness of the anger, anxiety and helplessness that students may feel when additional technology is introduced into their learning environment. Students' positive experiences of control, value and perceived success are also explored in this article. The authors recommend that we, as educators, need to understand the differences between the emotional supports that are required for learners depending on their study mode.

Sometimes our research findings come as a surprise to us. This is the case in Buchanan, Joban and Porter's exploration of psychology students' use of blogs, wikis and discussion boards (2014). Their two-year study of first year undergraduate 


\section{O’Reilly}

students in a 'Basic IT Skills in Psychology' course in the UK set out to find whether students' belief in their own self-efficacy when using the Internet is related to their attitudes towards and actual use of learning technologies.

Staying with the discipline of psychology, the next article, also from the UK, is a field study conducted by Stafford, Elgueta and Cameron (2014) into the use of wikis for collaborative learning. Their two-year study shows an impact of wiki use on exam marks for second and third year undergraduate students.

The next article by Kuikka, Kitola and Laasko (2014) compares three systems used for electronic exams in two higher education institutions in Finland. The in-house collaborative education platform ViLLE was shown to be most suitable as it addressed a range of requirements and preferences of the academics in their use of e-exams, the functional requirements online and the question formats. However, a key finding revealed that academics' attitudes, both those who embrace and those who resist technology, must be addressed if we expect e-exams to be adopted more broadly.

Staff attitudes and experiences in adoption of technology for teaching are also the focus of the next article by Reed (2014). Effective adoption that is aligned with core considerations of the Higher Education Funding Council of England - efficiency, enhancement and transformation - forms the touchstones of this inquiry. The institutional research reported in this article gives a clear outline of those elements of technology-enhanced learning that staff are both experienced and comfortable with, and which they use routinely in their teaching and assessment. The article also provides further reinforcement on factors of concern to staff - the ever-present challenges of time, digital literacy skills and the need for appropriate training and support.

The final article in this issue comes from the USA (Shively and Yerrick 2014). This case study, in which pre-service teachers effectively use technology in the science classroom, is an excellent example of embedding Mishra and Koehler's (2006) TPCK framework into teacher education. Furthermore, the experiential aspect of the teacher education program illustrates a way to shift pedagogical approaches from didactic to inquiry based, in keeping with the USA's national educational reforms.

This concludes a brief introduction to the considerable collection of articles in this issue. Many questions have come to mind for me from these works, such as:

- If responses to recommender systems reduce with age, then how can we make them more relevant to higher education students? Would a system that is based on ratings by student peers be a better tool for learners?

- Apart from requiring online students to create personal profile pages, what specific supports can reduce their sense of isolation, anxiety and helplessness at having to learn technology at the same time as learning their lessons?

- Can students' self-efficacy be harnessed for improved engagement with learning technologies?

- What can we make of the tension between use of a collaborative space for development of writing and critical thinking skills, versus the grade competition between student peers?

Hopefully, these and other questions arising from research published in this issue can stimulate future inquiry. Research stemming from works in this issue might build understanding of the influence of emotions, attitudes and perceptions on learning 
with technology, and explain how technology is helping us to deliver more studentcentred education.

Many thanks to the hard work of reviewers and the editorial panel for their constructive engagement with authors, and their attention to maintaining the journals' quality standards. Thanks also to the publishing team at Co-Action who play a vital role in managing the production of the journal articles and issues.

Dr Meg O’Reilly

Centre for Teaching and Learning Southern Cross University Australia

\section{References}

Blaschke, L. M. (2014) 'Using social media to engage and develop the online learner in selfdetermined learning', Research in Learning Technology, vol. 22, 21635, doi: http://dx.doi. org/10.3402/rlt.v22.21635

Buchanan, T., Jobanputra, S. \& Porter, A. (2014) 'Internet self-efficacy does not predict student use of Internet-mediated educational technology', Research in Learning Technology, vol. 22, 19585, doi: http://dx.doi.org/10.3402/rlt.v22.19585

Butz, N. T., Stupnisky, R. H. \& Pekrun, R. (2015) 'Students' emotions for achievement and technology use in synchronous hybrid graduate programmes: a control-value approach', Research in Learning Technology, vol. 23, 26097, doi: http://dx.doi.org/10.3402/rlt.v23. 26097

Kear, K., Chetwynd, F. \& Jefferis, H. (2014) 'Social presence in online learning communities: the role of personal profiles', Research in Learning Technology, vol. 22, 19710, doi: http:// dx.doi.org/10.3402/rlt.v22.19710

Kuikka, M., Kitola, M. \& Laakso, M.-J. (2014) 'Challenges when introducing electronic exam', Research in Learning Technology, vol. 22, 22817, doi: http://dx.doi.org/10.3402/rlt. v22.22817

Mishra, P. \& Koehler, M. (2006) 'Technological pedagogical content knowledge: a framework for teacher knowledge', Teachers College Record, vol. 108, no. 6, pp. 1017-1054.

Pedro, L., et al., (2014) 'The SAPO campus recommender system: a study about students' and teachers' opinions', Research in Learning Technology, vol. 22, 22921, doi: http://dx.doi.org/ $10.3402 /$ rlt.v22.22921

Reed, P. (2014) 'Staff experience and attitudes towards technology-enhanced learning initiatives in one Faculty of Health and Life Sciences', Research in Learning Technology, vol. 22, 22770, doi: http://dx.doi.org/10.3402/rlt.v22.22770

Stafford, T., Elgueta, H. \& Cameron, H. (2014) 'Students' engagement with a collaborative wiki tool predicts enhanced written exam performance', Research in Learning Technology, vol. 22, 22797, doi: http://dx.doi.org/10.3402/rlt.v22.22797

Shively, C. T. \& Yerrick, R. (2014) 'A case for examining pre-service teacher preparation for inquiry teaching science with technology', Research in Learning Technology, vol. 22, 21691, doi: http://dx.doi.org/10.3402/rlt.v22.21691 